\title{
Article
}

\section{Communities of practice, social learning and networks: Exploiting the social side of coach development}

\author{
Stoszkowski, J., and Collins, D.
}

Available at http://clok.uclan.ac.uk/11662/

Stoszkowski, J., ORCID: 0000-0002-1968-5770 and Collins, D. ORCID: 00000002-7601-0454 (2014) Communities of practice, social learning and networks: Exploiting the social side of coach development. Sport, Education and Society, 19 (6). pp. 773-788. ISSN 1357-3322

It is advisable to refer to the publisher's version if you intend to cite from the work. http://dx.doi.org/10.1080/13573322.2012.692671

For more information about UCLan's research in this area go to http://www.uclan.ac.uk/researchgroups/ and search for <name of research Group>.

For information about Research generally at UCLan please go to http://www.uclan.ac.uk/research/

All outputs in CLoK are protected by Intellectual Property Rights law, including Copyright law. Copyright, IPR and Moral Rights for the works on this site are retained by the individual authors and/or other copyright owners. Terms and conditions for use of this material are defined in the policies page.

\section{CLoK}

Central Lancashire online Knowledge www.clok.uclan.ac.uk

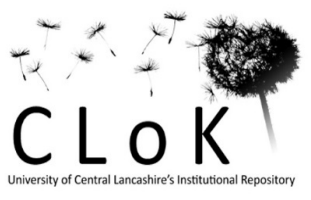


Communities of Practice, Social Learning and Networks: Exploiting the social side of coach development

John Stoszkowski* and Dave Collins

Institute of Coaching and Performance, University of Central Lancashire, U.K.

*Corresponding author. School of Sport, Tourism and The Outdoors. The University of Central Lancashire, Preston, PR1 2HE, UK. Email: JRStoszkowski@uclan.ac.uk

This is an Accepted Manuscript of an article published by Taylor \& Francis in Sport, Education and Society on $6^{\text {th }}$ June 2012, available online: http://dx.doi.org/10.1080/13573322.2012.692671 


\section{Communities of Practice, Social Learning and Networks: Exploiting the social side of coach development}

Large-scale coach education programmes have been developed in many countries, and are presented as playing a key role in the development of coaches and the promotion of high standards. Unfortunately, however, coaches often perceive that the current system of formal coach education fails to meet their needs. Perhaps as a result, the majority of their development is personally perceived to take place via informal and non-formal means. Appropriately, therefore, there has been an increasing focus within the coaching literature on the social aspects of learning, with social constructivist perspectives receiving particular attention. Reflecting this appropriate focus, this paper explores some of the potential opportunities and threats that social learning methods, such as Communities of Practice (CoP), present for coach developers. In tandem, we outline how all coaches are influenced by a set of pre-existing beliefs, attitudes and dispositions which are largely tempered by their experiences and interactions both with and within their social 'milieu'. We argue that, at the very least, we need to begin to understand these constructs and, if we do, the potential for coach developers to manipulate and exploit them is obvious. In conclusion, it is highlighted that whilst offering inherent challenges, CoPs and other social learning methods provide coach developers with a great opportunity and legitimate tool to change coach behaviour and raise coaching standards. Perhaps paradoxically, we also propose that formal coach education may still have a vital role to play in this process.

Keywords: coach education; epistemological beliefs; informal learning; nonformal learning; coach learning

\section{Introduction}

The continued inclusion of sport as an integral part of government policy (e.g. DCMS, 2012) and the subsequent increase in the scale and demand for sport coaching (McCullick et al., 2005) has led to the examination of coaching as an emerging professional area of activity, with an associated desire to raise vocational coaching standards (Gilbert \& Trudel, 1999; Lyle \& Cushion, 2010; Taylor \& Garret, 2010). In 
response, large-scale coach education programmes have been developed in many countries to help prepare coaches for their role (Nelson \& Cushion, 2006) and, once qualified, to enhance their further development.

These sport-specific courses operate at various levels, include well defined content based on role descriptors (e.g. assistant coach, club coach, advanced coach) and typically take a competency-based training approach to coach development (Wright et al., 2007). Thus, for coaches to be deemed competent and ready to coach, they must be able to demonstrate a minimum level of technical proficiency and instructional aptitude in a prescribed manner (cf. Abraham \& Collins, 1998; Cushion et al., 2003).

Consequently, and reflecting this central agenda, a great deal of formal coach education consists of a 'train and certify' approach (Trudel \& Gilbert, 2006) where the program developers direct what is to be learned and, it is assumed, coaches are able to acquire the concepts and skills they require (Mallett et al., 2009) before transferring and applying them effectively to the context in which they practice (Gilbert et al., 2009). Given that coaching certification is predominantly obtained after successful completion of a formal coach education programme, it is logical to assume that this source of learning would be the most impactful influence on coach behaviour. However, the limited academic literature available has been highly critical of such courses and suggests that coaches' needs are not being met with the current system. In fact, formal coach education is said to have a relatively low impact on coach learning (Gould et al., 1990; Saury \& Durand, 1998; Jones et al., 2003; Mallett et al., 2009; Sáiz et al., 2009; Cushion et al., 2010).

Instead, coaches resist formal educational opportunities and certifications, with pursuance of training reflecting a preference for informal and non-formal learning experiences including: a) self-directed learning experiences (Irwin et al., 2004; Nelson 
et al., 2006; Wright et al., 2007; Reade et al., 2008); b) past athletic experiences (Stewart \& Sweet, 1992; Cushion et al., 2003; Cushion, 2011); and c) coaching experiences, observations, and interactions with other coaches (Gould et al., 1990; Jones et al., 2003; Abraham et al., 2006; Cassidy \& Rossi, 2006). Furthermore, a variety of coaches' self-perceived limitations of, and resistance to, current formal provision have been outlined in existing research. These include financial and logistical concerns such as cost, location and timing (Trudel \& Gilbert, 2006; Vargas-Tonsing, 2007; Turner \& Nelson, 2009), a lack of context-specific relevance to course content (Cassidy et al., 2004; Hughes, 2005) together with negative experiences in terms of the consistency and quality of delivery, and a perceived lack of support from coach educators and other agencies (Gilbert \& Trudel, 1999; McCallister et al., 2000).

As a result, it appears that we have a body of coaches not influenced, or at least not willing to be influenced to any significant degree, by formal coach education and yet, still deemed 'competent' practitioners (Cushion, 2011) by this same 'questionable system'. Accordingly, there is an increasing acceptance within the coaching literature that the majority of coach development, at least as perceived by the recipients, occurs outside of formal educational settings (Cushion et al., 2003; Nelson et al., 2006). In tandem, the literature suggests that coach development is complex, largely individualised, and in many cases serendipitous (Cushion et al., 2003; Abraham et al., 2006; Cushion et al., 2010). In short, the system does not seem to be meeting the needs it was designed to meet!

\section{Is 'social' learning the answer?}

Perhaps as a result of this apparent preference for informal development, there has been an increasing focus on the social aspects of learning within the coaching literature. Most commonly, this entails 'social constructivist' perspectives of coach learning which 
purport that an individual 'constructs' knowledge through the direct experience of social practice and their interactions with others (Cushion, 2006; Cushion, 2011) rather than as a direct result of a formal educational process. This is exemplified, for example, in Lave and Wenger's (1996) concept of learning within a 'Community of Practice' (CoP), which is commonly cited as a mode of facilitating coach development (e.g. Cassidy et al., 2006; Culver \& Trudel, 2006) and which is certainly a central tool of national initiatives in the UK (UK Sport, 2010). Exponents of such approaches argue that, through social interaction, real-world practice and participation within communities of practice, learners are better able to construct meaning in practical ways so that knowledge may be more effectively applied, unconstrained by the more formal coach development settings (Gilbert \& Trudel, 2005).

Reflecting these concerns, we agree that, undeniably, social learning approaches provide a great opportunity for coach development. However, we also caution that careful investigation is needed on precisely how these concepts can influence both coach behaviour and learning for better and for worse. In extending this potential contribution, we suggest avenues for coach developers to exploit social learning as a legitimate tool in coach development provision. In similar fashion, however, we also suggest that social learning approaches, if managed incorrectly, could pose a significant threat to effective coach development and may simply serve to magnify and perpetuate many of the issues which coach developers should endeavour to nullify. In the discussion that follows we also suggest that, although formal coach education has its critics, these views are often self-perceived and yet to be checked against any accepted criteria of evaluation. Instead, we suggest that formal coach education may still have a vital role to play in the professionalization agenda, all be it, in a different guise to that in which we currently find it, or within which it is currently framed. 


\section{Underpinning theory: The social side of learning}

Undeniably, coaches are social beings operating in a social environment (Jones et al., 2002) and, for that reason, it is clear that knowledge is "socially constituted, socially mediated, and open ended" (Cushion et al., 2003, p. 221). Crucially however, although to date there has been a significant amount of work that has examined the social complexities of coaching practice itself (e.g. Bowes \& Jones, 2006; Cushion et al., 2006; Potrac \& Cassidy, 2006), insufficient attention has been paid to the fundamental social dimensions of coach development. Thus, while we may recognise and even, in part, understand that learning to coach is a 'socially mediated' activity, we lack the insight and guidelines which could enable us to optimise and exploit the process.

Traditionally, coach education has been underpinned by behavioural and cognitive educational perspectives and psychological conceptions of learning (Cushion et al., 2010). However, both the behaviourist and cognitivist approaches to learning fail to attend fully to social meaning and, it is suggested as an almost inevitable consequence, possess an inherent lack of social criticality (Cushion et al., 2003; Brockbank \& McGill, 2007). These approaches often seem to perceive knowledge to be neutral and value free, existing in a social vacuum detached from the wider world (Cushion et al., 2003; Jarvis, 2004). In effect, they view coaches as empty vessels waiting to be filled with coaching theory (Schempp \& Graber, 1992) ignoring the ongoing and inevitable social interactions against which such knowledge will be evaluated and applied.

In contrast, the social constructivist approach to learning contends that knowledge is a social construct and that we learn from and alongside other people in all our social relationships (Jarvis et al., 1998). Viewed from this perspective, learning is a collaborative process where knowledge is effectively co-constructed through interaction 
and negotiation (Sullivan, 1998). As such, knowledge is not just imposed from outside (as formal coach education attempts to do) but rather, is also formed inside the learner (Schunk, 2012) through an interactive process with both outside and inside influences. This view is, perhaps, best reflected in existing coach development research which concludes that coaches most often learn from other coaches (e.g. Gould et al., 1990; Salmela, 1995; Gilbert \& Trudel, 2005). For example, King (1990) suggests that it is the verbal interaction between peers that is the key to the construction of new knowledge or the process of transforming previous knowledge into new formats.

Alongside this perspective, theories of situated cognition have also brought the social construction of knowledge fully into focus (e.g. Brown et al., 1989; Lave \& Wenger, 1991; Wenger, 1998) and these theories demonstrate that learning happens best 'in context' as people attend to challenges and problems in their own environment. Reflecting this, Rogoff et al. (1995) suggest that there is no generic development that is independent of communities and their practices. Similarly, it has been suggested that the majority of coaches' learning should be situated in practice (Cushion et al., 2003) as this can remove much of the 'transfer distance' between learning and practice (another perceived limitation of formal coach education - Abraham et al., 2010).

\section{Communities of Practice: Only 'part of the answer'?}

In attending to these issues, a social constructivist approach to learning that has gained traction in recent years is Lave and Wenger's (1991) concept of learning within 'Communities of Practice' (CoP). Building on earlier work, Wenger (1998) and Wenger et al. (2002) propose that a CoP shares common elements, specifically a domain of knowledge, a community of people, and shared practices (Cassidy et al., (2004). Reflecting this, Culver and Trudel (2006, p. 98) define a coaching CoP as a "group of people [coaches] who share a common concern, set of problems, or a passion about a 
topic, and who deepen their knowledge and expertise in this area by interacting on an ongoing basis". St. Clair (1998) also depicts this type of learning community as a "sociocultural" phenomenon; it is the "site of cultural production and reproduction" (p. 8). Based on these various perspectives, it is apparent that these communities must be discursive; in short that is "discourse acts through communities to shape culture" (ibid., p. 9).

Crucially, however, we contend that, although learning within a $\mathrm{CoP}$ is determined by its members as a result of membership of and participation in the community (Wenger, 1998), learning is also shaped by what Billet and Somerville (2004) term the 'social press': that is, by historical, social, cultural, and institutional factors (Cushion, 2011) inherent within it. For example, the dialectical perspective of constructivism purports that knowledge is derived from the tension and interaction between an individual, situational and social factors, and the ever changing environment around them (Tusting \& Barton, 2006; Schempp, 1993). Similarly, informal learning has been acknowledged as "the lifelong process by which every person acquires and accumulates knowledge, skills, attitudes and insights from daily experiences and exposure to the environment" (Coombs \& Ahmed, 1974, p. 8).

Accordingly, and since much of a coach's work takes place in an intricate, multifaceted and wide ranging social setting (Cushion et al., 2010), it seems logical to assume that this setting will have a significant impact on coaches' construction of knowledge. This 'social milieu' can incorporate a wide range of significant others and multiple stakeholders (e.g. athletes, administrators, colleagues, role models, parents, policy makers, NGBs), who may all be working to varying agendas, with competing egos, and within complex hierarchies (Jones et al., 2002; Cushion et al., 2003; Abraham et al., 2010). In addition, the pervasive roots and influence of culture and tradition in 
sports run deep, and the proclaimed basics of 'how to coach' are explicitly repeated and reinforced in the testimony of more senior coaches, retired coaches and ex-athletes, as well as by articles published in the sports media (Grecic \& Collins, in press). Moreover, the media may 'sell' or promote certain coaching values which may either compliment or contradict the extant or dominant values. Consider, for example, the emphasis on long term player development as against current success. Existing literature has already purported that, within coaching society, winning is often the main aim and athletic achievement is subsequently equated with coaching prowess (Pankhurst \& Collins, in press).

Reflecting this complex and often contradictory set of influences, it is simply not possible to isolate a coach's development within a CoP from the social pressures that abound within the social environment (Jarvis, 1999). In essence, the social milieu will place pressure on developing coaches to behave in a certain way in order to conform (Collins et al., in press) while, in parallel, developing coaches will seek to conform to established stereotypes in order to secure approval from their more experienced 'fellow' coaches. The subtleties of this 'milieu' will also promote and perpetuate the value and acceptance of certain types of knowledge and behaviour over others (Cushion et al., 2003) and, whether consciously or subconsciously, guide what coaches choose to pay attention to as well as what they choose to learn (Werthner \& Trudel, 2006). For example, it is logical to assume that, if winning is emphasized within the social milieu, developing coaches are more likely to seek out knowledge in order to model their approach on professional or elite sport (Gilbert et al., 1999; McCallister et al., 2000; Gilbert \& Trudel, 2004), whether this is appropriate or not for the actual context in which they coach. Ultimately, people don't know what they don't know, and any motivation to participate in peer discussion on a particular topic will depend on the 
perceived benefits (Mallett et al., 2009) to the individual rather than an often amorphous, higher order target. If this is the case, how do coaches within a CoP decide which knowledge or behaviour to value and which to ignore? In short, against what standards do they judge what is good and not so good and, even more importantly, where do these standards come from? The point is that, in the absence of such 'focused criticality', social constructivism will be just as value laden, and may generate an equally flawed learning outcome, as the methods it is purported to supersede.

\section{Epistemology as a potential sieve}

One potential 'sieve' through which to evaluate quality is a coach's epistemology. Epistemological beliefs are an individual's beliefs about the nature of knowledge and how it is gained (Howard et al., 2000; Kaartinen-Koutaniemi \& Lindblom-Ylänne, 2008; Buehl \& Fives, 2009). Reflecting this, Pajares (1992, p. 316) uses the term 'belief' to refer to an "individual's judgement of the falsity of a proposition". These deeply held beliefs are at play in any learning experience, as every coaches' past experiences and interactions with and within the ever changing social milieu they inhabit and the way they frame their role, will (or at least should) screen or filter information which is most salient to them (Schempp \& Graber, 1992; Gilbert \& Trudel, 2004; Grecic \& Collins, in press).

Such beliefs may lead coaches to question the value of the information presented, make epistemic assumptions about the nature of coaching knowledge and question the validity of knowledge content (Fives \& Buehl, 2008). However, these beliefs are often unexamined and will influence how both future and practicing coaches approach the task of learning to coach, as well as the knowledge they construct from any learning experience (ibid). In addition, these beliefs are often anti-intellectual in nature and can be very difficult to change, which is a problem if the beliefs are in fact 
ill-judged (Ennis, 1994). Indeed, Tetlock (2005) refers to a 'cognitive conservatism' which outlines the reluctance of human beings to admit mistakes and update beliefs.

\section{Exploiting rather than just acknowledging social pressures: Can we use CoPs to change beliefs?}

Given the clear influence (for good and/or ill) which social pressures may exert, it is clear that identifying and directly challenging the ineffective values and practices promoted by the social milieu is crucial: accordingly, provoking debate amongst coaches and their peers, perhaps by introducing theory and evidence that provides a basis for this critical discussion (Abraham et al., 2010), is essential. Consequently, and perhaps paradoxically, CoPs themselves provide an interesting avenue for investigation in terms of achieving this aim; coach developers cannot ignore the embedded potential that $\mathrm{CoPs}$ have for challenging or altering existing norms and knowledge bases (Bitterman, 2000). Indeed, Damon (1984) suggests that any development that requires giving up current understanding to reach a new perspective might be best attained through interaction with peers.

It would seem, therefore, that CoPs can provide coach developers with an 'unrivalled opportunity' to encourage and enable coaches to critically examine the underlying beliefs that predominantly guide and influence their behaviour (Gilbert \& Trudel, 2004). In turn, the specific naïve beliefs and misconceptions that may be promoted by the social milieu and which may hinder the development of effective coaching practice might beneficially be identified and countered. Portnow et al. (1998, p. 22) refer to this as "transformational learning" as it enables the learner and their community to ponder critically, not only the veracity of knowledge and information, but also the bias and intentions of those creating that knowledge and information.

However, we would also contend that there is a 'clear and present' danger that a 
CoP may similarly serve as a mechanism to regurgitate and reinforce the values of the social milieu, unless the necessary focused criticality alluded to earlier plays a central role. In this regard, the epistemological chain (EC) can provide the link between a coach's philosophy, beliefs about knowledge and learning, and their demonstrated behaviour (Grecic \& Collins, in press). Research has already shown that coaches who are less developed are likely to have a less developed EC. Reflecting this, Stephenson and Jowett (2009) suggest that when coaches (especially novices) observe and interact with their peers (as they would in a CoP); they often almost unquestionably integrate (or even more concerningly, attempt to integrate) what they have observed into their own coaching practice. Likewise, Sage (1989) also demonstrated how neophyte coaches learn the dominant culture, what knowledge matters, and how they should act in the coaching environment from more senior coaches.

Unsurprisingly, the mere application of someone else's practices into one's own, simply because it sounds or looks better, may have negative ramifications for a coach's development and may also increase the likelihood of picking up bad habits (Stephenson \& Jowett, 2009). Conversely, those coaches with a more developed EC may simply look for information that agrees with or 'fits' their existing knowledge and belief structures. It is apparent, therefore, that if left unchecked, social constructivist learning methods (such as CoPs) provide the potential for coaches to pass on, and reiterate, harmful or ineffective practices and beliefs if knowledge is simply transferred between coaches without critical consideration of the ideas (Cushion et al., 2003; Reade et al., 2008).

\section{So what is the solution?}

We suggest that coaches may benefit from observing, interacting, and communicating with their peers in a CoP but only if they have a clear vision (e.g. a philosophical 
standpoint) of what underlying beliefs they may have, where those beliefs originate, and what type of coach they wish to become before joining (Stephenson \& Jowett, 2009). In short, if coaches were made aware of the foundations on which their own personal epistemology was based, they may then be able to make more conscious selections of their knowledge sources (Grecic \& Collins, in press). Reflecting these contentions, Bitterman (2000) concludes that individuals can most effectively collaborate and cocreate within a CoP when they have previously considered their own unique identity, have formed clear understandings of self, and are able to function in fairly autonomous ways. Thus for example, as a minimum requirement, presentations at CoPs should provide a clear context to what is being described, trace and make explicit the 'chain of reasoning' through which this particular combination of options were selected, describe some other options and finally, describe and discuss how the processes are evaluated and refined. Without this, the risk of 'halo led plagiarism' ( $\mathrm{s} / \mathrm{he}$ is good so I should do that) is often significant!

It seems necessary, therefore, for developing coaches to have a good sense of critique which they can apply to the wealth of information with which they are bombarded. Indeed, Hake (1999) suggests that an individual must develop a "reflexive biographical competency" in order to know more about how their previous experience and educational biography, as well as the learning setting, impacts upon their ability to learn (p. 87). In addition, according to Sullivan (1998), if a contradiction between a learner's existing understanding and what they experience can be created, this gives rise to a disequilibration which, in turn, can encourage the learner to question his or her beliefs and to try out new ideas. As an example, coaches should seek out and experience perspectives which disagree or cause dissonance with their current opinions and habits. Unfortunately, human nature tends us towards the exact opposite! 
One mechanism or coaching 'skill' to facilitate this process is that of becoming a reflective practitioner, which has received significant attention in recent years (e.g. Gilbert \& Trudel, 2001) and which is often proclaimed as the hallmark of professional competence (Larrivee, 2008). This research has utilised experiential learning theory and the role of the coach as experimenter (Schön, 1987) to examine coach development. In essence, the reflective practice approach both prescribes a method for understanding how coaches may have developed as a result of their previous experience, as well as outlining a means by which a coach can improve their ability to engage in reflective processes and, as a result, become 'better' at realising how they have improved. Consequently, it is assumed that a coach is then better able to make informed decisions about their future behaviour. Unfortunately, some systems fail to fully recognise, or exploit, the detail within Schön's work. For example, how many CoPs will ask coaches to discuss their 'experiments', or even 'socially sanction' those who claim, with pride, to "stay with what their experience helps them to know what works best" (cf. Collins et al., in press).

In this regard, whilst authors such as Gilbert and Trudel (2001) present a structure to guide the actual mechanics of reflection, if a coach is to be able to reflect critically on the origin and nature of their epistemological beliefs (as well as their practice) in order to maximise the development opportunities on offer through CoPs, how or where do they develop the skills to allow them to apply this process effectively? More to the point, how do they know which structures, issues, knowledge or information they should reflect against? Once again, the need for CoPs to share practice within a structure that requires the key context and associated decision making is clear.

Does formal coach development have a role to play?

If providing coaches with a critical awareness of their role frames is indeed a crucial 
element of personal and professional development (Gilbert \& Trudel, 2004), could it be that formal coach development programmes are the best place to help facilitate the development of these critical maxims? Instead of being a set of isolated activities or separate courses (Abraham \& Collins, 1998), formal coach education could become an ongoing system designed to expose coaches to the epistemology and the 'why' and 'what for' of their own beliefs and decision making, then to grow this along a structured and explicitly presented route. In addition, coaches could be provided with the structures and standards against which they should compare or measure these beliefs: at the very least, they should be asked to keep their own standards and structures explicitly in mind when evaluating the content of material shared at the CoP. This way, coaches are provided with the skills they need to effectively "formulate their own coaching beliefs and be able to make rational choices about the coaching methods, techniques and practices they develop" (Grecic \& Collins, in press). Additionally, in raising awareness of the social influences on beliefs and behaviours, coaches could become aware of the value laden nature of their practice (Jones, 2000), and likewise, how their actions in turn shape the social milieu in which they function (Cervero \& Wilson, 1999).

Clearly, this type of long term approach would contradict the current format of coach development in the UK, whereby courses are shorter and more explicit (i.e. 'do this' procedural rather than 'why/why not' declarative) the lower down the coaching structure you go (cf. Abraham \& Collins, 2011). In addition, researchers (e.g. Mallett, 2009) caution that there are other challenges for coach developers when attempting to implement fully functioning CoPs. For example, Wenger and Snyder (2000) describe CoPs as "organic, spontaneous, and informal" albeit "resistant to supervision and interference" (p. 140). Therefore, although cultivating these communities holds great potential for coach developers, their organic nature along with the likelihood that 
coaches will participate simultaneously in multiple communities, generates an unpredictable quality and can take control away from the coach developer (Bitterman, 2000). Indeed, according to Bitterman (2000), these groups may perhaps through the social pressures which we outline above actually undermine or defy established order and control. A criticism of the CoP approach is that there are rarely commonly defined aims and purposes and, even more rarely, a shared vocabulary and set of goals which will facilitate optimum communication of ideas and philosophies. Also, if there is knowledge being generated, how is the validity of this knowledge assured or quality controlled, especially for the inevitably varied needs of the various members? It could be, therefore, that rather than trying to 'control' the CoP, the coach developers' roles and responsibilities could include assisting CoPs to establish ground rules for discourse and to devise ways of monitoring their progress (Mallet \& Dickens, 2009).

\section{So what are the implications?}

If we are to accept and embrace more 'informal' methods of coach development (such as CoPs) as an alternative to the training and certification of coaches via formal coach education, and wish to encourage coaches to become truly autonomous learners, acknowledging the social processes at play in coach learning is essential. Firstly, if we are to understand and improve coach development, it is clear that we need to know more about coaches' beliefs, their priorities and how they rationalise their behaviours. In short, we need to understand and relate new knowledge to the aims, meta-cognition, planning and actions of individual coaches, whilst also enabling them to do this themselves. At the same time, it is also necessary to attempt to shine a light on why coaches value the types of knowledge they do. For example, understanding why (and perhaps challenging) why Coach A's actions are positive and effective would help the coach developer to ensure optimum benefit (rather than just blind copying) from the 
encounter. By gaining a deeper understanding of these constructs, we might then be able to facilitate the development of experiences and programming to encourage beliefs that support coaches' practice, motivation, and development and to target those beliefs that are less adaptive (Fives \& Buehl, 2008).

Secondly, we also need to know how the social milieu socialises coaches to fulfil expected roles, and how such influences can both constrain and liberate a coaches' development (Jones et al., 2003). Consequently, we need to look at the constructs that the community uses to judge coaching quality. For example, within a $\mathrm{CoP}$, a coach might assess the relevance of a topic or information based on the reputation of a coach within the CoP or wider social milieu. For example, 'it must be right because he says so' or 'his athletes are very good so what he says must be right'. This transgression of Hume's Law (confusing a 's/he is' with a 'we ought' cf. Collins \& MacNamara, in review) is both common and damaging; in simple terms, a champion performer does not necessarily have a champion coach (or a champion environment)!

Thirdly, coaches themselves need to increase their awareness of the social processes acting upon them during their development. If they do, they can become increasingly active in 'role-making' as opposed to merely 'role-playing' (Callero, 1994), and gain a better understanding of how their approaches to thinking, reasoning and behaviour affect their practice (Abraham et al., 2010). Therefore, in order to assist coaches to understand why they coach the way they do; coach developers need to encourage coaches to consider critically the construction and application of their professional knowledge (Hardy \& Mawer, 1999). As an example, coaches should focus on how they can be better within their current context, rather than through an uncritical consideration of someone else's situation.

Fourthly, we need to assist coaches in being confident and assertive enough 
when interacting with perhaps older, or more established peers, despite being comparatively 'fresh-faced' in their development. In this regard, how many leading coaches publically admit their failings (Collins et al., in press)? A recognition that everyone makes mistakes, indeed that mistake making is an inevitable and positive part of striving for a new competitive edge, should be a central tenet of CoPs. The process of peer supervision, common indeed required in some other professions (e.g. clinical and counselling psychology) is a good way to develop this balance.

Likewise, if coaches can be made aware of the processes necessary for the assimilation of personal epistemologies, perhaps they would also regulate their behaviours accordingly (Hung, 1998). For example, within the police force, it has been suggested that the use of certain attitudes (e.g. racism) are so widely accepted that such behaviour has become something of an occupational sub-culture (Onifade, 2002). Even if newer officers are fundamentally opposed to these attitudes, at least an appearance of their acceptance is often necessary in order to fit-in and 'survive' in the job, as well as to avoid being ostracised by colleagues, at least in the early stages. It would seem as hard to 'buck the trend' as a new coach as it is for a new police officer and yet both must be encouraged if we are to genuinely progress.

Consequently, we suggest it would be beneficial to engender an environment within coaching where expertise is not merely viewed as a product of accumulated experience or, even worse, time served. Likewise, coaches should be encouraged to challenge the established status quo, without feeling threatened, rather than perpetuate it and feel pressured 'to belong' (Onifade, 2002). Whilst 'shaking up' established practices can be a risky business, this risk can be minimised if coaches are given ways to engage with their peers that are invitational as opposed to confrontational (Larrivee, 2000). 
Finally, perhaps the biggest problem facing coach developers when developing new knowledge is that inappropriate beliefs already held by the coach must first be weakened in order to influence the acceptance of more 'correct' beliefs (Abraham \& Collins, 1998). It must be cautioned, however, that changing attitudes and behaviour is a notoriously difficult enterprise (Abraham et al., 2010). Nevertheless, if at the very least we can begin to understand the social milieu in which coaches operate, including the plethora of influences and sources of often conflicting information acting upon them, many of them subtle and perhaps unnoticed, and we can begin to identify and understand this social context of learning, as well as the tenets of social constructivism at play, coach developers could then begin to manipulate the social processes at work (for example within CoPs) in order to change coach behaviour and raise coaching standards.

\section{Conclusion}

Clearly, an array of potential talking points and areas for further investigation emerge from this discussion, and it is beyond the scope of this paper to address them all in sufficient depth. It is apparent, however, that coaches perceive that the current system of formal coach education fails to meet their needs, and instead, they show a preference for informal and non-formal learning experiences. Consequently, within the coaching literature, there has been a subsequent focus on the social aspects of coach development and 'social constructivist' perspectives of coach learning (e.g. CoPs) in particular.

However, despite social learning having several potential benefits as we have described thus far, a coach arrives at any learning opportunity with a pre-existing set of epistemological beliefs, attitudes and dispositions that have been, and continue to be, tempered by their experiences and interactions with their social milieu (Dodds, 1994). At the very least we need to begin to understand these constructs, and if we are really 
switched on, the potential for coach developers to manipulate and exploit them, alongside social constructivist approaches to learning, is obvious. If we do this, ultimately we may be able to influence coaches' epistemological beliefs, and subsequent coaching behaviour for the better.

Consequently, we suggest that, before we abandon formal coach education completely, we need to determine whether it could in fact be the ideal, if not the only place, for coaches to develop the critical faculties needed in order to bring these beliefs to the fore. We propose that the potential benefits of socially induced change in coach development are considerable, and viewing development through the psychosocial lens would allow coach developers to begin to create or enhance contexts for effective learning (Kilgore, 2004). Reflecting this, we suggest that further research is needed into this fruitful line in order to exploit the potential mechanisms for promoting change (Collins et al., in press), and as a result, enhance the professionalization agenda.

\section{References}

Abraham, A., Collins, D. \& Martindale, R. (2006) The coaching schematic: validation through expert coach consensus, Journal of Sports Sciences, 24 (6), 549-564.

Abraham, A., Muir, B. \& Morgan, G. (2010) UK Centre for Coaching Excellence scoping project report: national and international best practice in Level 4 coach development (Leeds, Leeds Metropolitan University).

Abraham, A. \& Collins, D. (1998) Examining and extending research in coach development, Quest, 50, 59-79.

Abraham, A. \& Collins, D. (2011). Taking the Next Step: Ways Forward for Coaching Science. Quest, 63, 366-384.

Billet, S. \& Somerville, M. (2004) Transformations at work: identity and learning, Studies in Continuing Education, 26 (2), 309-326. 
Bitterman, J. (2000) Learning communities., in: V. J. Marsick, J. Bitterman, \& R. van der Veen (Eds) From the learning organization to learning communities towards a learning society (Columbus, ERIC Clearinghouse on Adult, Career and Vocational Education), 21-34.

Bowes, I. \& Jones, R. L. (2006) Working at the edge of chaos: understanding coaching as a complex interpersonal system, The Sport Psychologist, 20, 235-245.

Brockbank, A. \& McGill, I. (2007) Facilitating reflective learning in higher education (Maidenhead, Open University Press).

Brown, J. S., Collins, A., \& Duguid, P. (1989) Situated cognition and the culture of learning, Educational Researcher, 18, 32-42.

Buehl, M. \& Fives, H. (2009) Exploring teachers' beliefs about teaching knowledge: where does it come from? Does it change? The Journal of Experimental Education, 77 (4), 367-407.

Callero, P. (1994) From role playing to role using: understanding role as a resource, Social Psychology Quarterly, 57 (3), 228-243.

Cassidy, T., Jones, R. \& Potrac, P. (2004) Understanding sports coaching: the social, cultural and pedagogical foundations of coaching practice (Abingdon, Routledge).

Cassidy, T., Potrac, P. \& McKenzie, A. (2006) Evaluating and reflecting upon a coach education initiative: the CoDe of rugby, The Sport Psychologist, 20 (2), 145-161.

Cassidy, T. \& Rossi, T. (2006) Situating learning: (Re)examining the notion of apprenticeship in coach education, International Journal of Sports Science and Coaching, 1 (3), 235-246.

Cervero, R. \& Wilson, A. (1999) Beyond learner-centred practice: adult education, power and society, Canadian Journal for the Study of Adult Education, 13 (2), 2738. 
Collins, D., Abraham, A. \& Collins, R. (in press) On vampires and wolves: exposing and exploring reasons for the differential impact of coach education, International Journal of Sport Psychology.

Collins, D. \& MacNamara, Á. (in review) A biopsychosocial perspective on talent development, Hume's Law and avoiding 'obvious' answers, Psychology of Sport and Exercise.

Coombs, P. H. \& Ahmed, M. (1974) Attacking rural poverty: how non-formal education can help (Baltimore, Johns Hopkins University Press).

Culver, D. \& Trudel, P. (2006) Cultivating coaches' communities of practice: developing the potential for learning through interactions, in: R. Jones (Ed) The sports coach as educator: reconceptualising sports coaching (London, Routledge), 97-112.

Cushion, C. (2006) Mentoring: harnessing the power of experience, in: R. L. Jones (Ed) The sports coach as educator, reconceptualisng sports coaching (London, Routledge), 128-144.

Cushion, C. (2011) Coaches' learning and development, in: I. Stafford (Ed) Coaching children in sport (London, Routledge), 57-69.

Cushion, C. (2011) Coach and athlete learning: a social approach, in: R. L. Jones, P. Potrac, C. Cushion \& L. Tore Ronglan (Eds) The sociology of sports coaching (London, Routledge), 166-178.

Cushion, C. J., Armour, K. M. \& Jones, R. L. (2003) Coach education and continuing professional development: experience and learning to coach, Quest, 55, 215-230.

Cushion, C. J., Armour, K. M. \& Jones, R. L. (2006) Locating the coaching process in practice: implications for coach education, Physical Education and Sport Pedagogy, 11 (1), 83-99. 
Cushion, C., Nelson, L., Armour, K., Lyle, J., Jones, R., Sandford, R. \& O’Callaghan, C. (2010) Coach learning and development: a review of literature (Leeds, Sports Coach UK).

Damon, W. (1984) Peer education: the untapped potential, Journal of Applied Behavioural Psychology, 5, 331-343.

DCMS (2012) Creating a sporting habit for life: a new youth sport strategy (London, DCMS).

Dodds, P. (1994) Cognitive and behavioural components of expertise in teaching physical education, Quest, 46, 143-163.

Ennis, C. D. (1994) Knowledge and beliefs underlying curricular expertise, Quest, 46, 164-175.

Fives, H. \& Buehl, M. M. (2008) What do teachers believe? Developing a framework for examining beliefs about teachers' knowledge and ability, Contemporary Educational Psychology, 33, 134-176.

Gilbert, W., Gallimore, R. \& Trudel, P. (2009) A learning community approach to coach development in youth sport, Journal of Coaching Education, 2 (2), 1-21.

Gilbert, W. D., Trudel, P. \& Haughian, L (1999) Interactive decision making factors considered by coaches of youth ice hockey during games, Journal of Teaching in Physical Education, 18, 290-311.

Gilbert, W. \& Trudel, P. (1999) An evaluation strategy for coach education programs, Journal of Sport Behavior, 22 (2), 234-250.

Gilbert, W. \& Trudel, P. (2004) Role of the coach: how model youth team sport coaches frame their roles, The Sport Psychologist, 18, 21-43.

Gilbert, W. D. \& Trudel, P. (2001) Learning to coach through experience: reflection in model youth sport coaches, Journal of Teaching in Physical Education, 21, 16-34. 
Gilbert, W. D. \& Trudel, P. (2005) Learning to coach through experience: conditions that influence reflection, Physical Educator, 62 (1), 32-43.

Gould, D., Gianinni, J., Krane, V. \& Hodge, K. (1990) Educational needs of elite U.S. national Pan American and Olympic coaches, Journal of Teaching in Physical Education, 9, 332-344.

Grecic, D. \& Collins, D. (in press) The epistemological chain: practical applications in sport, Quest.

Hardy, C. A. \& Mawer, M. (1999) Learning and teaching in physical education (London, Falmer).

Hake, B. J. (1999) Lifelong learning in late modernity: the challenges to society, organizations and individuals, Adult Education Quarterly, 49 (2), 79-90.

Howard, B. C., McGee, S., Schwartz, N. \& Purcell, S. (2000) The experience of constructivism: transforming teacher epistemology, Journal of Research on Computing in Education, 32 (4), 455-466.

Hughes, B. J. (2005) Identifying attitudes and deterring factors towards continuing education among certified athletic trainers, The Internet Journal of Applied Health Sciences and Practice, 3 (1), 1-14.

Hung, D. (1998) Epistemological change through peer apprenticeship learning: from rule-based to idea-based social constructivism, International Journal of Computers for Mathematical Learning, 3, 45-80.

Irwin, G., Hanton, S. \& Kerwin, D. G. (2004) Reflective practice and the origins of elite coaching knowledge, Reflective Practice, 5 (3), 425-442.

Jarvis, P. (1999) The practitioner research (San Francisco, Jossey-Bass).

Jarvis, P. (2004) Adult Education and lifelong learning: theory and practice (London, Routledge). 
Jarvis, P., Holford, J. \& Griffin, C. (1998) The theory and practice of learning (London, Kogan Page).

Jones, R. L. (2000) Toward a sociology of coaching, in: R. L. Jones \& K. M. Armour (Eds) Sociology of sport: theory and practice (London, Addison Wesley Longman), 33-43.

Jones, R. L., Armour, K. M. \& Potrac, P. (2002) Understanding the coaching process: a framework for social analysis, Quest, 54, 34-48.

Jones, R. L., Armour, K. M. \& Potrac, P. (2003) Constructing expert knowledge: a case study of a top-level professional soccer coach, Sport, Education and Society, 8, 213-229.

Kaartinen-Koutaniemi, M. \& Lindblom- Ylänne, S. (2008) Personal epistemology of psychology, theology and pharmacy students: a comparative study, Studies in Higher Education, 33 (2), 179-191.

Kilgore, D. (2004) Toward a postmodern pedagogy, New Directions for Adults and Continuing Education, 101, 45-53.

King, A. (1990) Peer interaction and learning in the classroom through reciprocal questioning, American Educational Research Journal, 27, 664-687.

Larrivee, B. (2000) Transforming teaching practice: becoming the critically reflective teacher, Reflective Practice, 1 (3), 293-307.

Larrivee, B. (2008) Development of a tool to assess teachers' level of reflective practice, Reflective Practice, 9 (3), 341-360.

Lave, J. \& Wenger, E. (1991) Situated learning: legitimate peripheral participation (Cambridge, Cambridge University Press).

Lave, J. \& Wenger, E. (1996) Practice, person, social world, in: H. Daniels (Ed) An introduction to Vygotsky (London, Routledge), 143-150. 
Lyle, J. \& Cushion, C. (Eds) (2010) Sports coaching: professionalisation and practice (Edinburgh, Churchill Livingstone Elsevier).

Mallett, C. J. \& Dickens, S. (2009) Authenticity in formal coach education, International Journal of Coaching Science, 3 (2), 79-90.

Mallett, C. J., Trudel, P., Lyle, J. \& Rynne, S. B. (2009) Formal vs. informal coach education, International Journal of Sports Science and Coaching, 4 (3), 325-333.

McCallister, S. G., Blinde, E. M. \& Kolenbrander, B. (2000) Problematic aspects of the role of youth sport coach, International Sports Journal, 4, 9-26.

McCallister, S. G., Blinde, E. M. \& Weiss, W. M. (2000) Teaching values and implementing philosophies: dilemmas of the youth sport coach, The Physical Educator, 57 (1), 34-45.

McCullick, B. A., Belcher, D. \& Schempp, P. G. (2005) What works in coaching and sport instructor certification programs? The participants' view, Physical Education and Sport Pedagogy, 10 (2), 121-137.

Nelson, L. J. \& Cushion, C. J. (2006) Reflection in coach education: the case of national governing body coaching certification, The Sport Psychologist, 20, 174-183.

Nelson, L. J., Cushion, C. J. \& Potrac, P. (2006) Formal, nonformal and informal coach learning: a holistic conceptualisation, International Journal of Sports Science and Coaching, 1, 247-259.

Onifade, D. (2002) The experience of black/minority ethnic police officers, support staff, special constables and resigners in Scotland (Edinburgh, Scottish Executive Central Research Unit).

Pajares, F. (1992) Teachers' beliefs and educational research: cleaning up a messy construct, Review of Educational Research, 62, 307-322. 
Pankhurst, A. \& Collins, D. (in press) Talent identification and development: the need for coherence between research, system and process, Quest.

Portnow, K., Popp, N., Broderick, M., Drago-Severson, E., \& Kegan, R. (1998) Transformational learning in adulthood, Focus on Basics, 2 (D), 22-27.

Potrac, P., \& Cassidy, T. (2006). The coach as 'a more capable other', in: R. Jones (Ed) The sports coach as educator: reconceptualising sports coaching (London, Routledge), 39-50.

Reade, I., Rodgers, W. \& Spriggs, K. (2008) New ideas for high performance coaches: a case study of knowledge transfer in sport science, International Journal of Sports Science and Coaching, 3 (3), 335-354.

Rogoff, B., Radziszewska, B. \& Masiello, T. (1995) Analysis of developmental processes in sociocultural activity, in: L. Martin, K. Nelson \& E. Tobach (Eds) Sociocultural psychology: theory and practice of doing and knowing (Cambridge, Cambridge University Press), 125-149.

Sage, G. (1989) Becoming a high school coach: from playing sport to coaching, Research Quarterly in Exercise and Sport, 60 (1), 81-92.

Sáiz, S., J., Calvo, A. L. \& Ibáñez Godoy, S. J. (2009) Development of expertise in Spanish elite basketball coaches, International Journal of Sport Science, 17 (5), $19-32$.

Salmela, J. (1995) Learning from the development of expert coaches, Coaching and Sport Science Journal, 2 (2), 3-13.

Saury, J. \& Durand, M. (1998) Practical knowledge in expert coaches: on site study of coaching in sailing, Research Quarterly for Exercise and Sport, 69 (3), 254-266. 
Schempp, P. (1993) Constructing professional knowledge: a case study of an experienced high school teacher, Journal of Teaching in Physical Education, 13 (1), 2-23.

Schempp, P. \& Graber, K. C. (1992) Teacher socialisation from a dialectical perspective: pre-training through induction, Journal of Teaching in Physical Education, 11, 329-348.

Schön, D. A. (1987) Educating the reflective practitioner (San Francisco, Jossey-Bass).

Schunk, D. H. (2012) Learning theories: an educational perspective (Boston, Allyn and Bacon).

St. Clair, R. (1998) On the commonplace: reclaiming community in adult education, Adult Education Quarterly, 49 (1), 5-14.

Stephenson, B. \& Jowett, S. (2009) Factors that influence the development of English youth soccer coaches, International Journal of Coaching Science, 3 (1), 3-16.

Stewart, C. F. \& Sweet, L. (1992). Professional preparation of high school coaches: the problem continues, The Journal of Health, Physical Education, Recreation, and Dance, 63 (2), 75-79.

Sullivan, A. S. (1998) Social constructivist perspectives on teaching and learning, Annual Review of Psychology, 49, 345-375.

Taylor, B. \& Garrat, D. (2010) The professionalization of sports coaching: definitions, challenges and critique, in: J. Lyle \& C. Cushion (Eds) Sports coaching: professionalisation and practice (Edinburgh, Churchill Livingstone Elsevier).

Tetlock, P. (2005) Expert political judgement: how good is it? How can we know? (New Jersey, Princeton University Press). 
Trudel, P. \& Gilbert, W. (2006) Coaching and coach education, in: D. Kirk, D. Macdonald \& M. O'Sullivan (Eds) Handbook of research in physical education (London, Sage), 516-539.

Turner, D. \& Nelson, L. J. (2009) Graduate perceptions of a UK university based coach education programme, and impacts on development and employability, International Journal of Coaching Science, 3 (2), 3-28.

Tusting, K. \& Barton, D. (2006) Models of adult learning: a literature review (Leicester, NIACE).

UK Sport (2010) Elite Coach. Available online at: http://www.uksport.gov.uk/pages/elite-coach/ (Accessed 20 March 2012).

Vargas-Tonsing, T. M. (2007) Coaches' preferences for continuing coaching education, International Journal of Sports Science and Coaching, 2 (1), 25-35.

Wenger, E. (1998) Communities of practice: learning, meaning, and identity (Cambridge, Cambridge University Press).

Wenger, E., McDermott, R. \& Snyder, W. (2002) Cultivating communities of practice: a guide to managing knowledge (Cambridge, Harvard University Press).

Wenger, E. C. \& Snyder, W. M. (2000) Communities of practice: the organizational frontier, Harvard Business Review, 78 (1), 139-145.

Werthner, P. \& Trudel, P. (2006) A new theoretical perspective for understanding how coaches learn to coach, The Sport Psychologist, 20, 198-212.

Wright, T., Trudel, P. \& Culver, D. (2007) Learning how to coach: the different learning situations reported by youth ice hockey coaches, Physical Education and Sport Pedagogy, 12 (2), 127-144. 